\title{
Litoreibacter albidus gen. nov., sp. nov. and Litoreibacter janthinus sp. nov., members of the class Alphaproteobacteria isolated from the seashore
}

\author{
Lyudmila A. Romanenko, ${ }^{1}$ Naoto Tanaka $^{2}$ Galina M. Frolova, ${ }^{1}$ \\ Vassilii I. Svetashev ${ }^{3}$ and Valery V. Mikhailov ${ }^{1}$ \\ ${ }^{1}$ Pacific Institute of Bioorganic Chemistry, Far-Eastern Branch, Russian Academy of Sciences, \\ 690022 Vladivostok, Prospect 100 Let Vladivostoku, 159, Russia \\ ${ }^{2}$ NODAl Culture Collection Center, Tokyo University of Agriculture, 1-1-1 Sakuragaoka, \\ Setagaya-ku, Tokyo 156-8502, Japan \\ ${ }^{3}$ Institute of Marine Biology, Far-Eastern Branch, Russian Academy of Sciences, 690041 \\ Vladivostok, Russia
}

Two Gram-negative, strictly aerobic, non-motile bacteria designated strains $\mathrm{KMM} 3851^{\top}$ and KMM $3842^{\top}$ were respectively isolated from a marine snail specimen (Umbonium costatum) and from surrounding sediments collected simultaneously from the shore of the Sea of Japan.

Phylogenetic analysis based on $16 \mathrm{~S}$ rRNA gene sequences showed that strains $\mathrm{KMM} 3851^{\top}$ and KMM $3842^{\top}$ were affiliated with the Roseobacter lineage of the class Alphaproteobacteria as a separate phylogenetic line adjacent to the members of the genus Thalassobacter. These novel isolates shared $98.5 \% 16 \mathrm{~S}$ rRNA gene sequence similarity and 15\% DNA-DNA relatedness. The major isoprenoid quinone of both strains was $\mathrm{Q}-10$ and polar lipids consisted of phosphatidylcholine, phosphatidylethanolamine, phosphatidylglycerol and aminophospholipids. In addition, strain $\mathrm{KMM} 3851^{\top}$ contained two unknown lipids, whereas strain $\mathrm{KMM} 3842^{\top}$ contained diphosphatidylglycerol. Fatty acid analysis revealed $\mathrm{C}_{18: 1} \omega 7 \mathrm{c}$ and $\mathrm{C}_{16: 0}$ as major components and small amounts of $\mathrm{C}_{18: 2}$. The DNA G+C contents were $60.4 \mathrm{~mol} \%\left(\mathrm{KMM} 3851^{\top}\right)$ and $58.5 \mathrm{~mol} \%\left(\mathrm{KMM} 3842^{\top}\right)$. Based on distinctive phenotypic characteristics, DNA-DNA hybridization data and phylogenetic distance, strains $\mathrm{KMM} 3851^{\top}$ and $\mathrm{KMM} 3842^{\top}$ should be classified as representatives of two novel species in a new genus, Litoreibacter gen. nov., with the type species Litoreibacter albidus sp. nov. (type strain $\mathrm{KMM} 3851^{\top}=\mathrm{NRIC} 0773^{\top}=\mathrm{JCM}$

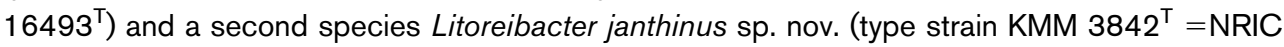
$0772^{\top}=$ JCM $16492^{\top}$ ).

The Roseobacter clade (order Rhodobacterales, class Alphaproteobacteria) constitutes a large group of genera (Garrity et al. 2005, 2006) that have been reported to be a significant component of marine and saline environments (Buchan et al., 2005). The number of genera in the Roseobacter clade is increasing continuously, with the recent addition of Thalassobius (Arahal et al., 2005), Thalassobacter (Macián et al., 2005; Pujalte et al., 2005),

Abbreviation: Bchl, bacteriochlorophyll.

The GenBank/EMBL/DDBJ accession numbers of the $16 \mathrm{~S}$ rRNA gene sequences of strains $\mathrm{KMM} 3842^{\top}$ and $\mathrm{KMM} 3851^{\top}$ are $\mathrm{AB} 518880$ and AB518881.

Three supplementary figures are available with the online version of this paper.
Shimia (Choi \& Cho, 2006), Donghicola (Yoon et al., 2007a), Pseudoruegeria (Yoon et al., 2007c) and Marivita (Hwang et al., 2009). The genera Phaeobacter and Marinovum (Martens et al., 2006) were recently proposed as a result of reclassification of Roseobacter gallaeciensis (Ruiz-Ponte et al., 1998) and Ruegeria algicola (Lafay et al., 1995; Uchino et al., 1998, 1999), respectively.

Here, we report the phenotypic and phylogenetic characterization of two strains, designated KMM $3851^{\mathrm{T}}$ and $\mathrm{KMM}$ $3842^{\mathrm{T}}$, which were isolated during a survey of the biodiversity of micro-organisms inhabiting shallow sediments of the Sea of Japan. Phylogenetic analysis based on $16 \mathrm{~S}$ rRNA gene sequences placed strains $\mathrm{KMM} 3851^{\mathrm{T}}$ and KMM $3842^{\mathrm{T}}$ within the Roseobacter lineage as a separate branch adjacent to the members of the genus Thalassobacter. 
Both strains exhibited distinguishing phenotypic and chemotaxonomic traits when compared with the closest phylogenetically related bacteria. Based on distinctive phenotypic characteristics, DNA-DNA hybridization data and phylogenetic distance, isolates $\mathrm{KMM} 3851^{\mathrm{T}}$ and $\mathrm{KMM}$ $3842^{\mathrm{T}}$ represent two species of a novel genus.

Strains $\mathrm{KMM} 3851^{\mathrm{T}}$ and $\mathrm{KMM} 3842^{\mathrm{T}}$ were respectively isolated from an internal tissue of a marine snail (Umbonium costatum; Gastropoda, Trochidae) and from a sample of the surrounding sediment, collected simultaneously from shallow sediment of the Sea of Japan, Russia, as described previously (Romanenko et al., 2004). Strains KMM $3851^{\mathrm{T}}$ and $\mathrm{KMM} 3842^{\mathrm{T}}$ were grown aerobically on marine 2216 agar (MA) or marine broth (MB) at $25-28{ }^{\circ} \mathrm{C}$ and stored at $-80{ }^{\circ} \mathrm{C}$ in liquid $\mathrm{MB}$ supplemented with $30 \%(\mathrm{v} / \mathrm{v})$ glycerol. Strains KMM $3851^{\mathrm{T}}$ and KMM $3842^{\mathrm{T}}$ were deposited in the Collection of Marine Micro-organisms (KMM), Pacific Institute of Bioorganic Chemistry, Vladivostok, Russia. Motility was determined by the hanging drop method as described by Gerhardt et al. (1994). Cells were observed by oil-immersion phase-contrast microscopy (AX70; Olympus) using 3-day cultures grown on MA at $25^{\circ} \mathrm{C}$. Gram staining, oxidase and catalase activities, hydrolysis of gelatin, casein, chitin, CM-cellulose, DNA and Tween 80 and $\mathrm{H}_{2} \mathrm{~S}$ production from thiosulfate were tested according to standard methods (Smibert \& Krieg, 1994). Acid production from carbohydrates was examined using oxidation/fermentation medium as described by Leifson (1963). Requirement for and tolerance of $\mathrm{NaCl}$ was tested on a medium based on artificial seawater (ASW) using various concentrations of $\mathrm{NaCl}$ in the range 0-20\%, supplemented with $\left(\mathrm{l}^{-1}\right) 10.0 \mathrm{~g}$ Bacto peptone, 2.0 g yeast extract, $0.028 \mathrm{~g} \mathrm{FeSO}_{4}$ and $15.0 \mathrm{~g}$ agar. The ASW contained (per litre distilled water): $24 \mathrm{~g}$ $\mathrm{NaCl}, 4.9 \mathrm{~g} \mathrm{MgCl}_{2}, 3.9 \mathrm{~g} \mathrm{Na}_{2} \mathrm{SO}_{4}, 1.1 \mathrm{~g} \mathrm{CaCl}_{2}, 0.66 \mathrm{~g} \mathrm{KCl}$, $0.2 \mathrm{~g} \mathrm{NaHCO}_{3}, 0.096 \mathrm{~g} \mathrm{KBr}, 0.026 \mathrm{~g} \mathrm{H}_{3} \mathrm{BO}_{3}, 0.024 \mathrm{~g} \mathrm{SrCl}_{2}$ and $0.003 \mathrm{~g} \mathrm{NaF}$ (Lyman \& Fleming, 1940). To test strains for sodium ion requirement, ASW was prepared without $\mathrm{NaNO}_{3}, \mathrm{NaSO}_{4}, \mathrm{NaHCO}_{3}$ and $\mathrm{NaF}$. In addition, strains were tested for growth on the above medium containing $\mathrm{NaCl}$ alone, without any of the sea salts components $\mathrm{MgCl}_{2}, \mathrm{KCl}$, $\mathrm{CaCl}_{2}, \mathrm{NaNO}_{3}, \mathrm{~K}_{2} \mathrm{HPO}_{4}, \mathrm{KCl}, \mathrm{NaSO}_{4}, \mathrm{NaHCO}_{3}, \mathrm{NaF}$ and $\mathrm{FeSO}_{4}$. Growth at different temperatures and $\mathrm{pH}$ and antibiotic resistance were studied as described previously (Romanenko et al., 2004, 2005). In addition, biochemical tests were carried out using API ZYM, API 32GN and API 20NE test kits (bioMérieux) according to the manufacturer's instructions, except that the cultures were suspended in ASW. Production of bacteriochlorophyll (Bchl) $a$ was tested spectrophotometrically in methanolic extracts of cells grown on MA and in MB in the dark, as described by Lafay et al. (1995). For polar lipid and fatty acid analyses, strains KMM $3851^{\mathrm{T}}$ and $\mathrm{KMM} 3842^{\mathrm{T}}$ were cultivated on MA at $28{ }^{\circ} \mathrm{C}$ for 3 days and lipids were extracted using the chloroform/ methanol extraction method of Bligh \& Dyer (1959). Polar lipids were analysed as described by Vaskovsky \& Terekhova (1979). Fatty acid methyl esters were obtained by alkaline methanolysis $(15 \% \quad \mathrm{NaOH} /$ methanol$)$, extracted with hexane and analysed using a GLC-MS Hewlett Packard model 6890 gas chromatograph equipped with an HP 5 MS $5 \%$ phenyl methyl siloxane capillary column (30 $\mathrm{m} \times$ $250 \mu \mathrm{m} \times 0.25 \mu \mathrm{m})$ and connected to a Hewlett Packard model 5973 mass spectrometer. Cells for respiratory lipoquinone analysis were obtained from $\mathrm{MB}$ cultures grown at $25{ }^{\circ} \mathrm{C}$. Isoprenoid quinones were extracted using chloroform/methanol $(2: 1, \mathrm{v} / \mathrm{v})$, purified by preparative TLC on silica gel 60 ADAMANT plates (Fluka) and analysed by HPLC (Agilent 1100 series) using a reversed-phase column (Hypersil ODS, $5 \mu \mathrm{m}$; $40 \times 250 \mathrm{~mm}$ ). Methanol/2propanol $(65: 35)$ was used as a mobile phase and quinones were detected at $270 \mathrm{~nm}$. The DNA base composition was determined as described by Marmur \& Doty (1962) and Owen et al. (1969). The photobiotin-labelled DNA probe microplate method described by Ezaki et al. (1989) was applied to determine DNA-DNA relatedness between strains KMM $3851^{\mathrm{T}}$ and KMM $3842^{\mathrm{T}}$. The $16 \mathrm{~S}$ rRNA gene sequences of strains $\mathrm{KMM} 3851^{\mathrm{T}}$ and $\mathrm{KMM} 3842^{\mathrm{T}}$, respectively containing 1440 and $1437 \mathrm{nt}$, were determined as described by Shida et al. (1997). The sequences obtained were compared with $16 \mathrm{~S}$ rRNA gene sequences retrieved from the EMBL/GenBank/DDBJ databases by using the FASTA program (Pearson \& Lipman, 1988). Phylogenetic analysis of $16 \mathrm{~S}$ rRNA gene sequences was performed using the software package MEGA 4 (Tamura et al., 2007) after multiple alignment of the data by CLUSTAL_X (version 1.83; Thompson et al., 1997). Phylogenetic trees were constructed by the neighbour-joining and maximum-parsimony methods and distances were calculated according to Kimura's two-parameter model. The robustness of phylogenetic trees was estimated by bootstrap analysis of 1000 replicates.

Comparative $16 \mathrm{~S}$ rRNA gene sequence analysis showed that isolates KMM $3851^{\mathrm{T}}$ and $\mathrm{KMM} 3842^{\mathrm{T}}$ were members of the class Alphaproteobacteria and were closely related to each other, with a sequence similarity of $98.5 \%$. Their closest phylogenetic neighbours were Thalassobacter arenae GA2$\mathrm{M}^{\mathrm{T}}{ }^{\mathrm{T}}$ (96.0 and $96.1 \%$ sequence similarity, respectively), Roseovarius crassostreae CV919-312 ${ }^{\mathrm{T}}$ (95.1 and 95.8\%), Pseudoruegeria aquimaris SW $-255^{\mathrm{T}}(94.7$ and $95.6 \%)$ and Sulfitobacter marinus SW-265 ${ }^{\mathrm{T}}$ (94.2 and $94.7 \%$ ). Different treeing algorithms (neighbour-joining and maximumparsimony) positioned strains $\mathrm{KMM} 3851^{\mathrm{T}}$ and $\mathrm{KMM}$ $3842^{\mathrm{T}}$ within the Roseobacter lineage of the Alphaproteobacteria as a separate branch adjacent to the members of the genus Thalassobacter (Fig. 1 and Supplementary Fig. S1). Low DNA-DNA relatedness of $15 \%$ was determined between strains KMM $3851^{\mathrm{T}}$ and KMM $3842^{\mathrm{T}}$, indicating that they belong to separate species (Wayne et al., 1987). As shown in Table 1, there are sufficient differences between these two genospecies in physiological and metabolic traits to allow their phenotypic identification.

Physiological, biochemical and chemotaxonomic characteristics of strains KMM $3851^{\mathrm{T}}$ and $\mathrm{KMM} 3842^{\mathrm{T}}$ are given in Tables 1 and 2, Supplementary Fig. S2 and in the genus and species descriptions. Strains KMM $3851^{\mathrm{T}}$ and KMM $3842^{\mathrm{T}}$ were Gram-negative, strictly aerobic, oxidase- and 


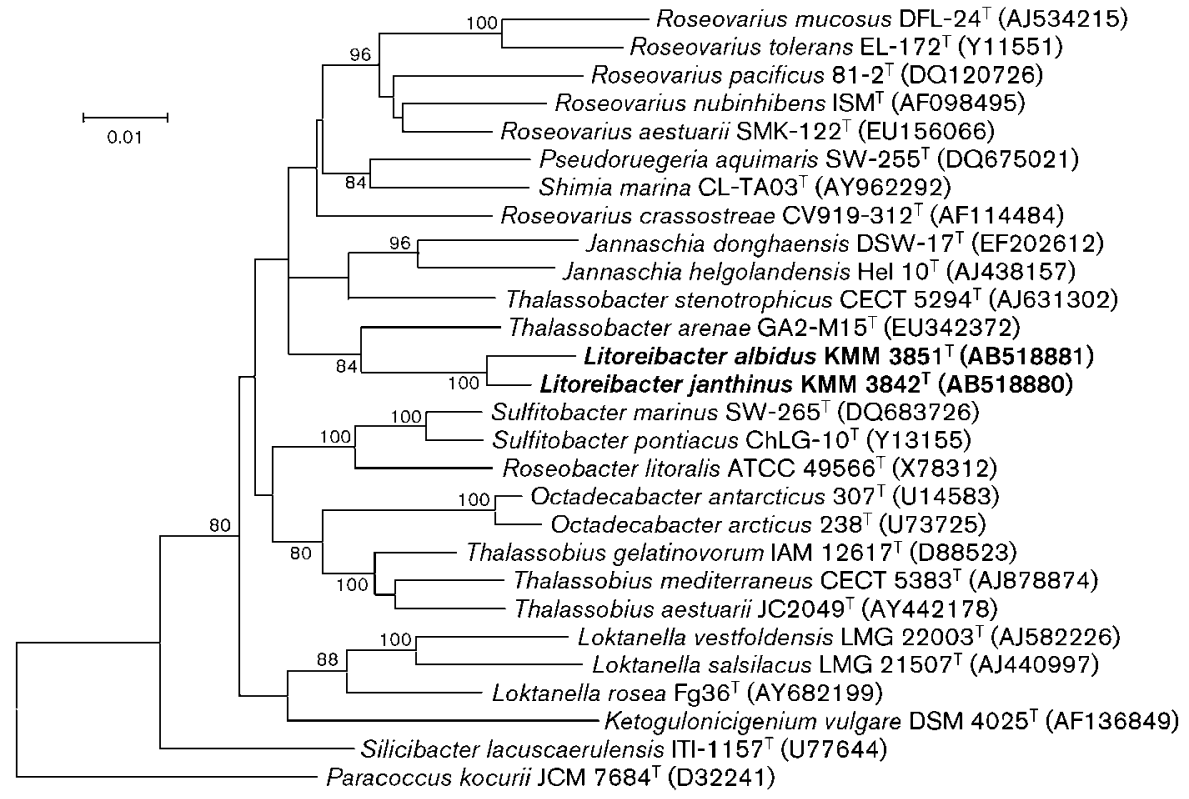

Fig. 1. Neighbour-joining phylogenetic tree based on $16 \mathrm{~S}$ rRNA gene sequences available from the GenBank/EMBL/DDBJ databases (accession numbers in parentheses) showing the relationship of isolates $\mathrm{KMM} 3851^{\top}$ and $\mathrm{KMM} 3842^{\top}$ and related genera of the class Alphaproteobacteria. Phylogenetic analysis was performed using the software package MEGA 4 (Tamura et al., 2007) after multiple alignment of data by CLUSTAL_x (version 1.83; Thompson et al., 1997). Bootstrap values greater than $70 \%$ based on 1000 replications are given at branching points. Bar, 0.01 substitutions per nucleotide position.

Table 1. Differential characteristics of strains $\mathrm{KMM} 3851^{\top}$ and $\mathrm{KMM} 3842^{\top}$ and related members of the Alphaproteobacteria

Taxa: 1, KMM 3851 ${ }^{\mathrm{T}} ; 2$, KMM 3842 $;$; , Thalassobacter stenotrophicus (unless indicated, data from Macián et al., 2005); 4, Thalassobacter arenae (Kim et al., 2009); 5, Jannaschia helgolandensis (Wagner-Döbler et al., 2003); 6, Jannaschia donghaensis (Yoon et al., 2007d); 7, Roseovarius crassostreae (Boettcher et al., 2005); 8, Pseudoruegeria aquimaris (Yoon et al., 2007c); 9, Sulfitobacter marinus (Yoon et al., 2007b). All bacteria are negative for gelatin hydrolysis. + , Positive; - , negative; $w$, weak reaction; ND, no data available.

\begin{tabular}{|c|c|c|c|c|c|c|c|c|c|}
\hline Characteristic & 1 & 2 & 3 & 4 & 5 & 6 & 7 & 8 & 9 \\
\hline Pigmentation ${ }^{\star}$ & WH & GV & SP & $\mathrm{BR}$ & WH & $\mathrm{O}$ & $\mathrm{PB}$ & GY & $\mathrm{C}$ \\
\hline Bchl $a$ & - & - & + & ND & ND & - & - & $\mathrm{ND}$ & $\mathrm{ND}$ \\
\hline Motility & - & - & + & + & - & - & + & - & - \\
\hline \multicolumn{10}{|l|}{ Growth at: } \\
\hline $4{ }^{\circ} \mathrm{C}$ & + & + & - & - & - & + & - & - & + \\
\hline $37^{\circ} \mathrm{C}$ & + & $\mathrm{w}$ & + & - & - & - & + & + & - \\
\hline$>37{ }^{\circ} \mathrm{C}$ & - & - & - & - & - & - & - & + & - \\
\hline $\mathrm{NaCl}$ range for growth (\%) & $0.5-8$ & $0.5-6$ & $0.85-7$ & $0.85-8$ & $1-7$ & $\mathrm{ND}$ & ND & $\mathrm{ND}$ & $\mathrm{ND}$ \\
\hline Nitrate reduction & - & - & - & - & - & - & + & - & - \\
\hline $\mathrm{H}_{2} \mathrm{~S}$ production & + & - & - & ND & ND & - & ND & - & - \\
\hline D-Glucose assimilation & - & - & $+\dagger$ & + & + & - & - & + & - \\
\hline$\beta$-Galactosidase & + & + & - & + & ND & - & - & + & - \\
\hline \multicolumn{10}{|l|}{ Hydrolysis of: } \\
\hline Aesculin & + & + & + & + & - & - & - & + & - \\
\hline Tween 80 & + & - & - & ND & - & $\mathrm{w}$ & $\mathrm{ND}$ & - & + \\
\hline Tyrosine & + & - & - & $\mathrm{w}$ & $\mathrm{ND}$ & - & $\mathrm{ND}$ & - & + \\
\hline DNA G + C content $(\mathrm{mol} \%)$ & 60.4 & 58.5 & 59 & 56 & $63.0-63.1$ & 65.2 & 59 & 67.0 & 57.8 \\
\hline
\end{tabular}

${ }^{\star} \mathrm{BR}$, Brown; C, cream; GV, greyish violet; GY, greyish yellow; O, orange; $\mathrm{PB}$, pinkish beige; SP, salmon pink; wH, whitish.

$\dagger$ Data from Kim et al. (2009). 
Table 2. Fatty acid and polar lipid compositions of strains $\mathrm{KMM} 3851^{\top}$ and $\mathrm{KMM} 3842^{\top}$ and related members of the Alphaproteobacteria

Taxa: 1, KMM 3851 ${ }^{\mathrm{T}}$; 2, KMM 3842 ${ }^{\mathrm{T}}$; 3, Thalassobacter arenae (data from Kim et al., 2009); 4, Thalassobacter stenotrophicus (fatty acids, Macián et al., 2005; polar lipids, Kim et al., 2009); 5, Jannaschia helgolandensis (Wagner-Döbler et al., 2003); 6, Jannaschia donghaensis (Yoon et al., 2007d); 7, Roseovarius crassostreae (Boettcher et al., 2005); 8, Pseudoruegeria aquimaris (Yoon et al., 2007c); 9, Sulfitobacter marinus (Yoon et al., 2007b). Values for fatty acids are percentages of total fatty acids; - , not detected. Polar lipids are indicated as present $(+)$ or absent $(-)$. ND, No data available.

\begin{tabular}{|c|c|c|c|c|c|c|c|c|c|}
\hline Component & 1 & 2 & 3 & 4 & 5 & 6 & 7 & 8 & 9 \\
\hline $\mathrm{C}_{10} 3-\mathrm{OH}$ & 2.2 & 3.2 & 3.7 & 3.2 & 5.6 & 1.5 & $2.1 \pm 0.3$ & 2.9 & 3.6 \\
\hline $\mathrm{C}_{16: 0}$ & 10.3 & 11.9 & 10.4 & 0.4 & - & - & $3.6 \pm 0.9$ & 1.4 & 8.3 \\
\hline $\mathrm{C}_{17: 0}$ & 1.0 & - & - & 0.3 & 1.0 & 1.8 & - & 0.9 & 0.7 \\
\hline $\mathrm{C}_{18: 2}$ & 2.3 & 2.8 & - & - & - & - & - & - & - \\
\hline 11-Methyl $C_{18: 1} \omega 7 c$ & - & - & 5.9 & 7.0 & 5.7 & 6.9 & $0.8 \pm 0.2$ & 2.8 & 6.9 \\
\hline $\mathrm{C}_{18: 0}$ & 1.0 & 1.4 & 1.2 & 2.6 & 10.8 & 5.2 & $0.7 \pm 0.3$ & 6.6 & 0.6 \\
\hline $\mathrm{C}_{19: 1}$ & 1.3 & 10.5 & - & - & - & - & - & - & - \\
\hline $\mathrm{C}_{19: 0}$ & - & - & - & - & - & 5.9 & - & - & - \\
\hline $\mathrm{C}_{19: 1} / \mathrm{C}_{19: 0}$ cyclo & - & - & - & 1.5 & 2.9 & - & - & - & - \\
\hline $\mathrm{C}_{19: 0}$ cyclo $\omega 8 c$ & - & - & - & - & - & 25.1 & - & 5.9 & - \\
\hline Phosphatidylethanolamine & + & + & + & + & + & + & $\mathrm{ND}$ & + & $\mathrm{ND}$ \\
\hline Phosphatidylglycerol & + & + & + & + & + & + & $\mathrm{ND}$ & + & $\mathrm{ND}$ \\
\hline Diphosphatidylglycerol & - & + & + & + & + & - & ND & + & $\mathrm{ND}$ \\
\hline \multicolumn{10}{|l|}{ Unidentified components } \\
\hline Aminophospholipid(s) & + & + & - & - & - & - & $\mathrm{ND}$ & - & $\mathrm{ND}$ \\
\hline Aminolipid(s) & - & - & - & - & + & - & ND & - & $\mathrm{ND}$ \\
\hline Phospholipid(s) & - & - & - & + & - & - & $\mathrm{ND}$ & + & $\mathrm{ND}$ \\
\hline $\operatorname{Lipid}(s)$ & + & - & - & - & - & - & $\mathrm{ND}$ & - & ND \\
\hline Glycolipid(s) & - & - & - & - & - & + & ND & + & ND \\
\hline
\end{tabular}

catalase-positive, non-fermentative, heterotrophic, nonmotile and rod-shaped bacteria that were enlarged at one pole, indicating cell division by budding (Supplementary Fig. S3). Strains KMM $3842^{\mathrm{T}}$ and KMM $3851^{\mathrm{T}}$ differed from each other in colony pigmentation, as they formed greyish-violet and whitish colonies, respectively, when grown on MA at $4-30{ }^{\circ} \mathrm{C}$. However, strain KMM $3851^{\mathrm{T}}$ was able to produce diffusible greenish-violet pigment during cultivation at $35{ }^{\circ} \mathrm{C}$ on $\mathrm{MA}$ and other media. In addition, the strains could be distinguished by growth in $8 \% \mathrm{NaCl}$, hydrolysis of Tween 80 and L-tyrosine and $\mathrm{H}_{2} \mathrm{~S}$ production (Table 1). They also yielded different results in carbon source assimilation tests (API 32GN): strain KMM $3851^{\mathrm{T}}$ assimilated acetate, D-mannitol, melibiose, propionic acid, potassium 2-ketogluconate, 3-hydroxybutyric acid and L-proline, whereas KMM $3842^{\mathrm{T}}$ could not assimilate any compounds that were included on the API 32GN strip.

The major isoprenoid quinone was determined to be Q-10 in both strains. Polar lipids of both strains consisted of phosphatidylcholine, phosphatidylethanolamine, phosphatidylglycerol and an unknown aminophospholipid. In addition, strain $\mathrm{KMM} 3851^{\mathrm{T}}$ contained two unknown lipids, whereas KMM $3842^{\mathrm{T}}$ contained diphosphatidylglycerol (Supplementary Fig. S2). Fatty acid analysis revealed $\mathrm{C}_{18: 1} \omega 7 c$ and $\mathrm{C}_{16: 0}$ as dominant components. The chemotaxonomic properties of strains KMM $3851^{\mathrm{T}}$ and $\mathrm{KMM} 3842^{\mathrm{T}}$ (ubiquinone Q-10, the predominance of $\mathrm{C}_{18: 1} \omega 7 c$ and the presence of phosphatidylcholine, phosphatidylethanolamine, phosphatidylglycerol) are similar to those reported for phylogenetically related genera of the Roseobacter clade. At the same time, strains $\mathrm{KMM} 3851^{\mathrm{T}}$ and KMM $3842^{\mathrm{T}}$ differed substantially from their phylogenetic relatives in the presence of an unknown aminophospholipid and the absence of 11-methyl $\mathrm{C}_{18: 1} \omega 7 c, \mathrm{C}_{20: 1} \omega 7 c$ and $\mathrm{C}_{19: 0}$ cyclo in their fatty acid and polar lipid profiles (Table 2).

The DNA $\mathrm{G}+\mathrm{C}$ contents determined for strains $\mathrm{KMM}$ $3851^{\mathrm{T}}$ and $\mathrm{KMM} 3842^{\mathrm{T}}$ (60.4 and $58.5 \mathrm{~mol} \%$, respectively) were close to the values reported for Thalassobacter 
stenotrophicus and Roseovarius crassostreae (both $59 \mathrm{~mol} \%$ ) and Sulfitobacter marinus (57.8 mol\%) and slightly higher than the value of $56 \mathrm{~mol} \%$ reported for Thalassobacter arenae, but were clearly distinct from values reported for Jannaschia species (63.0-65.2 $\mathrm{mol} \%)$ and Pseudoruegeria aquimaris (67.0 mol\%) (Table 1$)$.

The phylogenetic distinctiveness found for strains KMM $3851^{\mathrm{T}}$ and $\mathrm{KMM} 3842^{\mathrm{T}}$ was supported by a combination of phenotypic characteristics that allowed them to be differentiated from closely related bacteria. Both isolates could be distinguished from their closest relative Thalassobacter arenae KACC $12675^{\mathrm{T}}$ in morphological characteristics, including cell dimensions $(0.4-0.6 \mu \mathrm{m}$ wide and $1.8-$ $2.0 \mu \mathrm{m}$ long, against $0.7-1.2 \mu \mathrm{m}$ wide and $1.2-2.4 \mu \mathrm{m}$ long for Thalassobacter arenae), immobility, the presence of budding cell division, colony pigmentation, growth at 4 and $37^{\circ} \mathrm{C}$ and the inability to assimilate D-glucose and most carbohydrates (Table 1) and in fatty acid and polar lipid profiles (Table 2). Based on their distinctive phenotypic characteristics and phylogenetic distance, strains KMM $3851^{\mathrm{T}}$ and KMM $3842^{\mathrm{T}}$ are considered to represent a new genus, Litoreibacter gen. nov., with two novel species, the type species Litoreibacter albidus sp. nov. (type strain $\mathrm{KMM} 3851^{\mathrm{T}}$ ) and a second species, Litoreibacter janthinus sp. nov. (type strain KMM $3842^{\mathrm{T}}$ ).

\section{Description of Litoreibacter gen. nov.}

Litoreibacter (Li.to.re'i.bac'ter. L. adj. litoreus belonging to the seashore; N.L. masc. n. bacter a rod; N.L. masc. n. Litoreibacter rod from the seashore).

Gram-negative, strictly aerobic, oxidase- and catalasepositive, rod-shaped bacteria that are enlarged at one pole due to cell division by budding. Chemo-organoheterotrophic. Sodium ions are essential for growth. The predominant isoprenoid quinone is Q-10. Polar lipids include phosphatidylcholine, phosphatidylethanolamine, phosphatidylglycerol, diphosphatidylglycerol, aminophospholipids and unknown lipids. The major fatty acid is $\mathrm{C}_{18: 1} \omega 7 c$, followed by $\mathrm{C}_{16: 0}$. On the basis of $16 \mathrm{~S}$ rRNA gene sequence analysis, the genus represents a separate branch within the Alphaproteobacteria, closely related to the genera Thalassobacter, Jannaschia and Pseudoruegeria. Known strains have been isolated from marine environments. The type species is Litoreibacter albidus.

\section{Description of Litoreibacter albidus sp. nov.}

Litoreibacter albidus (al'bi.dus. L. masc. adj. albidus white).

In addition to the properties given in the genus description, the species is characterized as follows. Cells are 0.4-0.6 $\mu \mathrm{m}$ in diameter and 1.8-2.0 $\mu \mathrm{m}$ long. Non-motile. Produces whitish-pigmented, smooth, shiny colonies with regular edges, $2-3 \mathrm{~mm}$ in diameter, on MA. Greenish-violet diffusible pigment is observed during cultivation at $35{ }^{\circ} \mathrm{C}$. $\mathrm{Bchl} a$ is not produced. Requires $\mathrm{NaCl}$ for growth; growth occurs at $0.5-8 \% \mathrm{NaCl}(\mathrm{w} / \mathrm{v})$ and is optimal in $2-3 \% \mathrm{NaCl}$ (w/v). Grows in/on basal medium containing $\mathrm{NaCl}$ alone without any of the sea salts components $\mathrm{MgCl}_{2}, \mathrm{KCl}, \mathrm{CaCl}_{2}$, $\mathrm{NaNO}_{3}, \mathrm{~K}_{2} \mathrm{HPO}_{4}, \mathrm{KCl}, \mathrm{NaSO}_{4}, \mathrm{NaHCO}_{3}, \mathrm{NaF}$ and $\mathrm{FeSO}_{4}$. Psychrotolerant; the temperature range for growth is 4$37{ }^{\circ} \mathrm{C}$ with an optimum at $25-28{ }^{\circ} \mathrm{C}$. No growth is observed above $37^{\circ} \mathrm{C}$. Grows at $\mathrm{pH} 6.0-10.0$ with an optimum at $\mathrm{pH}$ 7.5-8.5. Negative for hydrolysis of casein, gelatin, DNA, chitin and starch. Positive for $\mathrm{H}_{2} \mathrm{~S}$ production and hydrolysis of Tween 80 and L-tyrosine. On L-tyrosinecontaining medium, melanin-like pigments are not produced but a clearance zone is formed. No acid production is observed from D-glucose, maltose, sucrose, lactose, D-galactose, D-mannose, cellobiose, D-xylose, L-arabinose, L-rhamnose, D-sorbitol or D-mannitol. In API 20NE tests, positive for $\beta$-galactosidase (PNPG test) and aesculin hydrolysis and negative for nitrate reduction, indole production, glucose acidification under anaerobic conditions, gelatin hydrolysis, arginine dihydrolase, urease and assimilation of D-glucose, L-arabinose, D-mannose, D-mannitol, $\mathrm{N}$-acetylglucosamine, maltose, D-gluconate, caprate, adipate, L-malate, citrate and phenylacetate. In ID32 GN tests, assimilates sodium acetate, D-mannitol, melibiose, propionic acid, potassium 2-ketogluconate, 3-hydroxybutyric acid and L-proline and does not assimilate L-rhamnose, $\mathrm{N}$-acetylglucosamine, D-ribose, inositol, sucrose, maltose, itaconic acid, suberic acid, sodium malonate, lactic acid, L-alanine, potassium 5-ketogluconate, glycogen, 3-hydroxybenzoic acid, L-serine, D-glucose, salicin, L-fucose, D-sorbitol, L-arabinose, capric acid, valeric acid, trisodium citrate, L-histidine or 4-hydroxybenzoic acid. In API ZYM tests, positive for alkaline phosphatase, esterase (C4), esterase lipase (C8), leucine arylamidase, acid phosphatase and naphthol-AS-BI-phosphohydrolase and negative for lipase (C14), valine arylamidase, cystine arylamidase, trypsin, $\alpha$-chymotrypsin, $N$-acetyl- $\beta$-glucosaminidase, $\alpha$-galactosidase, $\beta$-galactosidase, $\alpha$-glucosidase, $\beta$-glucuronidase, $\beta$-glucosidase, $\alpha$-mannosidase and $\alpha$-fucosidase. The detailed compositions of fatty acids and polar lipids are given in Table 2. Susceptible to ( $\mu$ g per disc unless indicated) ampicillin (10), benzylpenicillin (10 U), carbenicillin (100), gentamicin (10), rifampicin (5), streptomycin (30), vancomycin (30), kanamycin (30), nalidixic acid (30), ofloxacin (5), polymyxin (300 U), oxacillin (10), erythromycin (15), cephazolin (30), cephalexin (30), tetracycline (30) and chloramphenicol (30) and resistant to lincomycin (15), neomycin (30) and oleandomycin (15). The DNA G +C content of the type strain is $60.4 \mathrm{~mol} \%$ (thermal denaturation method).

The type strain is KMM $3851^{\mathrm{T}}\left(=\mathrm{NRIC} 0773^{\mathrm{T}}=\mathrm{JCM}\right.$ $16493^{\mathrm{T}}$ ), isolated from the internal tissues of a marine snail specimen (Umbonium costatum) collected from shallow sediments of the Sea of Japan, Russia.

\section{Description of Litoreibacter janthinus sp. nov.}

Litoreibacter janthinus (jan'thi.nus. L. masc. adj. janthinus violet-blue). 
In addition to the properties given in the genus description, the species is characterized as follows. Cells are 0.4$0.6 \mu \mathrm{m}$ in diameter and 1.8-2.0 $\mu \mathrm{m}$ long. Non-motile. Produces greyish-violet-pigmented colonies with regular edges, $2-3 \mathrm{~mm}$ in diameter, on MA. Bchl $a$ is not produced. Requires $\mathrm{NaCl}$ for growth; growth occurs at $0.5-6 \% \mathrm{NaCl}(\mathrm{w} / \mathrm{v})$ and is optimal in $2-3 \% \mathrm{NaCl}(\mathrm{w} / \mathrm{v})$. Grows in/on basal medium containing $\mathrm{NaCl}$ alone without any of the sea salts components $\mathrm{MgCl}_{2}, \mathrm{KCl}, \mathrm{CaCl}_{2}$, $\mathrm{NaNO}_{3}, \mathrm{~K}_{2} \mathrm{HPO}_{4}, \mathrm{KCl}, \mathrm{NaSO}_{4}, \mathrm{NaHCO}_{3}, \mathrm{NaF}$ and $\mathrm{FeSO}_{4}$. Psychrotolerant; temperature range for growth is $4-37{ }^{\circ} \mathrm{C}$, with an optimum at $25-28{ }^{\circ} \mathrm{C}$. No growth is observed above $37^{\circ} \mathrm{C}$. Grows at $\mathrm{pH} 6.0-10.0$, with an optimum at $\mathrm{pH}$ 7.0-8.5. Negative for $\mathrm{H}_{2} \mathrm{~S}$ production and hydrolysis of casein, gelatin, DNA, Tween 80, chitin, starch and Ltyrosine. On L-tyrosine-containing medium, melanin-like pigments and clearance zones are not produced. No acid production from D-glucose, maltose, sucrose, lactose, D-galactose, D-mannose, cellobiose, D-xylose, L-arabinose, L-rhamnose, D-sorbitol or D-mannitol. In API 20NE tests, positive for gelatin hydrolysis and $\beta$-galactosidase (PNPG test) and negative for nitrate reduction, indole production, glucose acidification under anaerobic conditions, arginine dihydrolase, urease production, gelatin hydrolysis and assimilation of D-glucose, L-arabinose, D-mannose, D-mannitol, $\mathrm{N}$-acetylglucosamine, maltose, D-gluconate, caprate, adipate, L-malate, citrate and phenylacetate. In ID32 GN tests, does not assimilate L-rhamnose, $\mathrm{N}$-acetylglucosamine, D-ribose, inositol, sucrose, maltose, itaconic acid, suberic acid, sodium malonate, sodium acetate, lactic acid, L-alanine, potassium 5-ketogluconate, glycogen, 3-hydroxybenzoic acid, L-serine, D-mannitol, D-glucose, salicin, melibiose, L-fucose, D-sorbitol, L-arabinose, propionic acid, capric acid, valeric acid, trisodium citrate, L-histidine, potassium 2-ketogluconate, 3-hydroxybutyric acid, 4-hydroxybenzoic acid or L-proline. In API ZYM tests, positive for alkaline phosphatase, esterase lipase (C8), leucine arylamidase, valine arylamidase, acid phosphatase, $\alpha$-glucosidase and $\beta$-glucosidase, weakly positive for naphthol-AS-BI-phosphohydrolase and negative for esterase (C4), lipase (C14), trypsin, $\alpha$-chymotrypsin, cystine arylamidase, $N$-acetyl- $\beta$-glucosaminidase, $\alpha$-galactosidase, $\beta$-galactosidase, $\beta$-glucuronidase, $\alpha$-mannosidase and $\alpha$-fucosidase. Susceptible to ( $\mu \mathrm{g}$ per disc unless indicated) ampicillin (10), benzylpenicillin (10 U), carbenicillin (100), gentamicin (10), lincomycin (15), oleandomycin (15), rifampicin (5), streptomycin (30), vancomycin (30), kanamycin (30), nalidixic acid (30), neomycin (30), ofloxacin (5), polymyxin (300 U), erythromycin (15), cephazolin (30), cephalexin (30), chloramphenicol (30), oxacillin (10) and tetracycline (30). Detailed fatty acid and polar lipid compositions are listed in Table 2. The DNA $\mathrm{G}+\mathrm{C}$ content of the type strain is $58.5 \mathrm{~mol} \%$ (thermal denaturation method).

The type strain, KMM $3842^{\mathrm{T}}\left(=\right.$ NRIC $0772^{\mathrm{T}}=\mathrm{JCM}$ $\left.16492^{\mathrm{T}}\right)$, was isolated from a shallow sediment sample collected from the Sea of Japan, Russia.

\section{Acknowledgements}

This study was supported by a grant from the Presidium of RAS 'Molecular and Cell Biology', by the Federal Agency for Science and Innovations of the Russian Federation (State Contract 02.518.11. 7169) and by a grant from Presidium Far-Eastern Branch of Russian Academy of Sciences (09-III-A-06_227).

\section{References}

Arahal, D. R., Macián, M. C., Garay, E. \& Pujalte, M. J. (2005). Thalassobius mediterraneus gen. nov., sp. nov., and reclassification of Ruegeria gelatinovorans as Thalassobius gelatinovorans comb. nov. Int $J$ Syst Evol Microbiol 55, 2371-2376.

Bligh, E. G. \& Dyer, W. J. (1959). A rapid method of total lipid extraction and purification. Can J Biochem Physiol 37, 911-917.

Boettcher, K. J., Geaghan, K. K., Maloy, A. P. \& Barber, B. J. (2005). Roseovarius crassostreae sp. nov., a member of the Roseobacter clade and the apparent cause of juvenile oyster disease (JOD) in cultured Eastern oysters. Int J Syst Evol Microbiol 55, 1531-1537.

Buchan, A., Gonzalez, J. M. \& Moran, M. A. (2005). Overview of the marine Roseobacter lineage. Appl Environ Microbiol 71, 5665-5677.

Choi, D. H. \& Cho, B. C. (2006). Shimia marina gen. nov., sp. nov., a novel bacterium of the Roseobacter clade isolated from biofilm in a coastal fish farm. Int J Syst Evol Microbiol 56, 1869-1873.

Ezaki, T., Hashimoto, Y. \& Yabuuchi, E. (1989). Fluorometric deoxyribonucleic acid-deoxyribonucleic acid hybridization in microdilution wells as an alternative to membrane filter hybridization in which radioisotopes are used to determine genetic relatedness among bacterial strains. Int J Syst Bacteriol 39, 224-229.

Garrity, G. M., Bell, J. A. \& Lilburn, T. (2005). Order III. Rhodobacterales ord. nov. In Bergey's Manual of Systematic Bacteriology, 2nd edn, vol. 2C, p. 161. Edited by D. J. Brenner, N. R. Krieg, J. T. Staley \& G. M. Garrity. New York: Springer.

Garrity, G. M., Bell, J. A. \& Lilburn, T. (2006). Order III. Rhodobacterales ord. nov. In List of New Names and New Combinations Previously Effectively, but not Validly, Published, Validation list no. 107. Int J Syst Evol Microbiol 56, 1-6.

Gerhardt, P., Murray, R. G. E., Wood, W. A. \& Krieg, N. R. (editors) (1994). Methods for General and Molecular Bacteriology. Washington, DC: American Society for Microbiology.

Hwang, C. Y., Bae, G. D., Yih, W. \& Cho, B. C. (2009). Marivita cryptomonadis gen. nov., sp. nov. and Marivita litorea sp. nov., of the family Rhodobacteraceae, isolated from marine habitats. Int J Syst Evol Microbiol 59, 1568-1575.

Kim, B. Y., Weon, H. Y., Son, J. A., Lee, C. M., Hong, S. B., Jeon, Y. A., Koo, B. S. \& Kwon, S. W. (2009). Thalassobacter arenae sp. nov., isolated from sea sand in Korea. Int J Syst Evol Microbiol 59, 487-490.

Lafay, B., Ruimy, R., Rausch de Traubenberg, C., Breittmayer, V., Gauthier, M. J. \& Christen, R. (1995). Roseobacter algicola sp. nov., a new marine bacterium isolated from the phycosphere of the toxinproducing dinoflagellate Prorocentrum lima. Int J Syst Bacteriol 45, 290-296.

Leifson, E. (1963). Determination of carbohydrate metabolism of marine bacteria. J Bacteriol 85, 1183-1184.

Lyman, J. \& Fleming, R. H. (1940). Composition of sea water. J Mar Res 3, 1183-1184.

Macián, M. C., Arahal, D. R., Garay, E., Ludwig, W., Schleifer, K. H. \& Pujalte, M. J. (2005). Thalassobacter stenotrophicus gen. nov., sp. nov., a novel marine $\alpha$-proteobacterium isolated from Mediterranean sea water. Int J Syst Evol Microbiol 55, 105-110. 
Marmur, J. \& Doty, P. (1962). Determination of the base composition of deoxyribonucleic acid from its thermal denaturation temperature. J Mol Biol 5, 109-118.

Martens, T., Heidorn, T., Pukall, R., Simon, M., Tindall, B. J. \& Brinkhoff, T. (2006). Reclassification of Roseobacter gallaeciensis RuizPonte et al. 1998 as Phaeobacter gallaeciensis gen. nov., comb. nov., description of Phaeobacter inhibens sp. nov., reclassification of Ruegeria algicola (Lafay et al. 1995) Uchino et al. 1999 as Marinovum algicola gen. nov., comb. nov., and emended descriptions of the genera Roseobacter, Ruegeria and Leisingera. Int J Syst Evol Microbiol 56, 1293-1304.

Owen, R. J., Hill, L. R. \& Lapage, S. P. (1969). Determination of DNA base composition from melting profiles in dilute buffers. Biopolymers 7, 503-516.

Pearson, W. R. \& Lipman, D. J. (1988). Improved tools for biological sequence comparison. Proc Natl Acad Sci U S A 85, 2444-2448.

Pujalte, M. J., Macián, M. C., Arahal, D. R. \& Garay, E. (2005). Thalassobacter stenotrophicus Macián et al. 2005 is a later synonym of Jannaschia cystaugens Adachi et al. 2004, with emended description of the genus Thalassobacter. Int J Syst Evol Microbiol 55, 1959-1963.

Romanenko, L. A., Schumann, P., Rohde, M., Mikhailov, V. V. \& Stackebrandt, E. (2004). Reinekea marinisedimentorum gen. nov., sp. nov., a novel gammaproteobacterium from marine coastal sediments. Int J Syst Evol Microbiol 54, 669-673.

Romanenko, L. A., Uchino, M., Falsen, E., Frolova, G. M., Zhukova, N. V. \& Mikhailov, V. V. (2005). Pseudomonas pachastrellae sp. nov., isolated from a marine sponge. Int J Syst Evol Microbiol 55, 919924.

Ruiz-Ponte, C., Cilia, V., Lambert, C. \& Nicolas, J. L. (1998). Roseobacter gallaeciensis sp. nov., a new marine bacterium isolated from rearings and collectors of the scallop Pecten maximus. Int J Syst Bacteriol 48, 537-542.

Shida, O., Takagi, H., Kadowaki, K., Nakamura, L. K. \& Komagata, K. (1997). Transfer of Bacillus alginolyticus, Bacillus chondroitinus, Bacillus curdlanolyticus, Bacillus glucanolyticus, Bacillus kobensis, and Bacillus thiaminolyticus to the genus Paenibacillus and emended description of the genus Paenibacillus. Int J Syst Bacteriol 47, 289298.

Smibert, R. M. \& Krieg, N. R. (1994). Phenotypic characterization. In Methods for General and Molecular Bacteriology, pp. 607-655. Edited by P. Gerhardt, R. G. E. Murray, W. A. Wood \& N. R. Krieg. Washington, DC: American Society for Microbiology.
Tamura, K., Dudley, J., Nei, M. \& Kumar, S. (2007). MEGA 4: molecular evolutionary genetics analysis (MEGA) software version 4.0. Mol Biol Evol 24, 1596-1599.

Thompson, J. D., Gibson, T. J., Plewniak, F., Jeanmougin, F. \& Higgins, D. G. (1997). The CLUSTAL_X windows interface: flexible strategies for multiple sequence alignment aided by quality analysis tools. Nucleic Acids Res 25, 4876-4882.

Uchino, Y., Hirata, A., Yokota, A. \& Sugiyama, J. (1998). Reclassification of marine Agrobacterium species: proposals of Stappia stellulata gen. nov., comb. nov., Stappia aggregata sp. nov., nom. rev., Ruegeria atlantica gen. nov., comb. nov., Ruegeria gelatinovora comb. nov., Ruegeria algicola comb. nov., and Ahrensia kieliense gen. nov., sp. nov., nom. rev. J Gen Appl Microbiol 44, 201210.

Uchino, Y., Hirata, A., Yokota, A. \& Sugiyama, J. (1999). Ruegeria algicola comb. nov. In Validation of the Publication of New Names and New Combinations Previously Effectively Published Outside the IJSB, List no. 68. Int J Syst Bacteriol 49, 1-3.

Vaskovsky, V. E. \& Terekhova, T. A. (1979). HPTLC of phospholipid mixtures containing phosphatidylglycerol. J High Resol Chromatogr Chromatogr Comm 2, 671-672.

Wagner-Döbler, I., Rheims, H., Felske, A., Pukall, R. \& Tindall, B. J. (2003). Jannaschia helgolandensis gen. nov., sp. nov., a novel abundant member of the marine Roseobacter clade from the North Sea. Int J Syst Evol Microbiol 53, 731-738.

Wayne, L. G., Brenner, D. J., Colwell, R. R., Grimont, P. A. D., Kandler, O., Krichevsky, M. I., Moore, L. H., Moore, W. E. C., Murray, R. G. E. \& other authors (1987). International Committee on Systematic Bacteriology. Report of the ad hoc committee on reconciliation of approaches to bacterial systematics. Int J Syst Bacteriol 37, 463-464.

Yoon, J. H., Kang, S. J. \& Oh, T. K. (2007a). Donghicola eburneus gen. nov., sp. nov., isolated from seawater of the East Sea in Korea. Int $J$ Syst Evol Microbiol 57, 73-76.

Yoon, J. H., Kang, S. J. \& Oh, T. K. (2007b). Sulfitobacter marinus sp. nov., isolated from seawater of the East Sea in Korea. Int J Syst Evol Microbiol 57, 302-305.

Yoon, J. H., Lee, S. Y., Kang, S. J., Lee, C. H. \& Oh, T. K. (2007c). Pseudoruegeria aquimaris gen. nov., sp. nov., isolated from seawater of the East Sea in Korea. Int J Syst Evol Microbiol 57, 542-547.

Yoon, J. H., Kang, S. J., Park, S. \& Oh, T. K. (2007d). Jannaschia donghaensis sp. nov., isolated from seawater of the East Sea, Korea. Int J Syst Evol Microbiol 57, 2132-2136. 